\title{
Miejsca sabatów czarownic w epoce wczesnonowożytnej - ich znaczenie i topografia. Przyczynek do badań nad procesami o czary na Śląsku i Morawach
}

\section{Summary}

The locations of witch Sabbaths in early modern era - their significance and topographic specificity. Contributions to research on witchcraft trials in Silesia and Moravia

There are many stereotypes related to witches and witch trials in the public's imagination. One of the popular elements associated to this issue is the question of the witches' Sabbath, which the witches attended. The Sabbath itself is a collection of the fantasies of late medieval and early modern society, with specific features depending on the region. Researchers assume that the sources of the meetings that later became known as the Sabbath were those attributed to heretics who worshiped the devil during them. This meeting was characterized by a certain order of rituals and customs. They could take place not only on such characteristic days as April 30, but also a week, up to three times. According to testimonies, witches arrived at the Sabbath on broomsticks or pitchforks, and during the meeting an orgy would often take place. These meetings took place in special places, mainly on various hills. The most famous mountains, where the Sabbaths took place, are Blocksberg in the Harz Mountains, Łysa Góra, and when it comes to the border area of Silesia and Moravia - Petrovy Kameny, which appear in large numbers in the testimonies of people accused of witchcraft in this area. This place, which is located on the border of the estate, was considered to be full of the forces of darkness, therefore in 1682 it was decided to consecrate it. Very often specific areas or regions "had" their own mountain where witch meetings took place. The Sabbaths could also take place in less obvious places, e.g. in clearings, trees, road branches or near the gallows. In some cases, in memory of such meetings, characteristic names such as Hexenplan or Hexenplatz remained, which not only can be found on old maps, but also function to this day in designated areas.

Keywords: witch, wittches sabbath, witch trials, Silesia, Moravia, Petrovy Kameny, Łysa Góra, Blocksberg 


\section{Streszczenie}

W wyobraźni społeczeństwa funkcjonuje wiele stereotypów związanych z czarownicami, jak i z procesami o czary. Jednym z popularnych elementów związanych z tym zagadnieniem jest kwestia sabatu czarownic, na który owe uczęszczały. Sam sabat jest zbiorem fantazji późnośredniowiecznego i wczesnonowożytnego społeczeństwa, o specyficznych cechach, zależnych od regionu. Badacze wychodzą z założenia, że źródłem spotkań, które później zyskały miano sabatu, były te przypisywane heretykom, którzy podczas nich czcili diabła. Spotkanie to cechował pewien porządek rytuałów i obyczajów. Odbywać się one mogły nie tylko w takie charakterystyczne dni jak 30 kwietnia, lecz także w tygodniu, nawet do trzech razy. Według zeznań czarownice przylatywały na sabat na miotłach lub widłach, a podczas spotkania nierzadko miało dochodzić do orgii. Do spotkań tych dochodziło w szczególnych miejscach, przede wszystkim na różnego rodzaju wzniesieniach. Do najbardziej znanych gór, gdzie odbywały się sabaty, należą Blocksberg w Górach Harzu, Łysa Góra, a jeśli chodzi o pograniczne śląsko-morawskie - Petrovy Kameny, które licznie pojawiają się w zeznaniach osób oskarżonych o czary na tym obszarze. Miejsce to, które znajduje się na dawnym pograniczu dóbr, uchodziło za pełne sił ciemności, stąd też w 1682 r. zdecydowano się je poświęcić. Bardzo często konkretne obszary czy regiony „miały” własną górę, gdzie dochodziło do spotkań czarownic. Sabaty mogły się także odbywać w mniej oczywistych miejscach, np. na polanach, drzewach, rozgałęzieniach dróg czy w pobliżu szubienicy. W niektórych przypadkach na pamiątkę takich spotkań pozostały charakterystyczne nazwy, takie jak: Hexenplan czy Hexenplatz, które nie tylko można znaleźć na starych mapach, lecz także funkcjonują one do dzisiaj na wyznaczonych terenach.

Słowa kluczowe: czarownica, sabat, procesy o czary, Śląsk, Morawy, Petrovy Kameny, Łysa Góra, Blocksberg

$\mathrm{P}$ olowania na czarownice, których nasilenie nastąpiło w epoce wczesnonowożytnej, na stałe wprowadziło utrzymujące się do dzisiaj pewne stereotypy w masowej wyobraźni społeczeństwa. Do przykładowych możemy zaliczyć np. wizerunek czarownicy, jej płeć, średniowiecze jako epokę największych prześladowań czarownic, latanie na miotle, tortury, którym były poddawane jako jedyne, oraz sabat, czyli domniemane spotkanie czarownic, podczas którego m.in. czczono szatana. Sama idea sabatu jest zagadnieniem niezwykle interesującym. Coraz częściej powstają nie tylko liczne opracowania analizujące schemat ich przebiegu opisywany podczas przesłuchań, lecz także prace mające na celu odkrycie pojawienia się idei takich spotkań oraz jej rozwój ${ }^{1}$. Termin ten ma również interesujące pochodzenie. Początkowo słowo to występowało wraz ze słowami „szabas” i „szabat” jako określenie święta żydowskiego ${ }^{2}$. Według Marco Frenschkowskiego ma to związek z próbą demo-

1 M. Ostling, Introduction to the Special Issue. How (and Why) Do Witches Fly?, „Magic, Ritual, and Witchcraft" 2016, vol. XI, No. 1, s. 1-5. Ciekawe ujęcie tematu w pracy magisterskiej z zakresu historii sztuki vide: D. Gruber, Der Hexensabbat. Zeitgenössische Darstellungen auf illustrierten Flugblättern, Graz 2013 (maszynopis), https://www.academia.edu/33137136/Master_Thesis_Art_History_Der_ Hexensabbat_Zeitgen\%C3\%B6ssische_Darstellungen_auf_illustrierten_Flugbl\%C3\%A4ttern_ Graz_2013_online_unter_http_permalink_obvsg_at_AC11065819_(dostęp: 1 IX 2020). Cf. też: M. Oziębłowski, Motyw lotu czarownic w tzw. „zbiorczej koncepcji” czarownictwa europejskiego. Świadectwa średniowieczne i wczesnonowożytne, „Almanach Historyczny” 2003, t. V, s. 49-74.

2 Sabat, [w:] Stownik jezzyka polskiego, https://sjp.pwn.pl/poradnia/haslo/szabas-szabat-sabat;6819. html (dostęp: 3 IX 2020). 
nizowania judaizmu, co można także zauważyć we francuskim synonimie spotkania czarownic, mianowicie synagogue ${ }^{3}$. W drugiej połowie XX w., wskutek specjalizacji w języku polskim, terminy „szabat” $\mathrm{i}$ „szabas” zachowały pierwsze znaczenie, natomiast słowo „sabat” przyjęło drugie, czyli domniemane spotkanie diabła i czarownic ${ }^{4}$.

Sabat, jak zauważył badacz procesów o czary Wolfgang Behringer, jest zbiorem fantazji późnośredniowiecznego i wczesnonowożytnego społeczeństwa, o specyficznych cechach, które zależne były od regionu. Badacze wychodzą z założenia, że źródłem spotkań, które później zyskały miano sabatu, były te odbywane przez heretyków, którzy podczas nich czcili diabła ${ }^{5}$. W legendarnym już dziele Mtot na czarownice ${ }^{6}$ spotkania czarownic nie odgrywają znaczącej roli. Sytuacja zmieniła się wraz z natężeniem procesów o czary. Podczas tortur i przesłuchań zeznania związane z sabatem pozwalały kierować podejrzenia na kolejne osoby, które rzekomo miały w nich uczestniczyć ${ }^{7}$. Analizując przebieg sabatu, zauważono również podobieństwa do zachowań występujących podczas obrzędów pogańskich, takich jak np. dziki taniec. Także daty sabatów nierzadko pokrywały się z dawnymi świętami pogańskimi ${ }^{8}$. Przyjęło się stwierdzenie, że idea sabatu pojawiła się wśród inkwizytorów i duchowieństwa pod wpływem pozostałości obrzędów i rytuałów pogańskich? . Obecnie pojawiają się głosy, że osobami, które „stworzyły” wizję sabatu, byli przede wszystkim demonolodzy i oskarżyciele w procesach o czary ${ }^{10}$.

Temat sabatu wciąż nie został wyczerpany. Pojawiają się coraz to nowe ujęcia problemu i próby wyjaśnienia konceptu nie tylko sabatów, lecz także tego, w jaki sposób czarownice się tam dostawały, oraz jak mogły przebiegać spotkania. Liczne opisy zawarte w zeznaniach tworzą konkretną historię, z wieloma szczegółami. Opis i analiza przebiegu sabatu według zeznań konkretnych morawskich i śląskich czarownic oraz ich kompatybilność z najczęściej występującymi opisami z innych obszarów europejskich zasługuje na osobny artykuł; w tym miejscu jedynie scharakteryzuję najczęściej pojawiające się informacje o sabatach. Dzieliły się one na tzw. wielkie i powszednie. Pierwsze z nich odbywały się w konkretne dni, jednym z najpopularniejszych była

M. Frenschkowski, Die Hexen. Eine kulturgeschichtliche Analyse, Wiesbaden 2016, s. 179.

Sabat...

E. Potkowski, Czary i czarownice, Warszawa 1970, s. 285.

6 Przez wieki autorstwo tego dzieła przypisywano Jakobowi Sprengerowi i Heinrichowi Kramerowi. Obecnie coraz więcej naukowców przychyla się do opinii, że autorem był jedynie Kramer. Vide: H. Kramer (Institoris), Der Hexenhammer. Malleus Maleficarum, przekł. z laciny W. Behringer, G. Jerouschek, W. Tschacher, München 2000, s. 31 i n.; M.D. Bailey, Battling Demons. Witchcraft, Heresy, and Reform in the Late Middle Ages, University Park 2003, s. 3, 48-49.

7 W. Behringer, Hexensabbat, [w:] Enzyklopädie der Neuzeit, Bd. V, hrsg. F. Jaeger, Stuttgart 2007, s. 432.

$8 \quad$ E. Potkowski, op. cit., s. 285.

9 Ibidem, s. 287. Więcej na temat sabatów: C. Ginzburg, Hexensabbat. Entzifferung einer nächtlichen Geschichte, Berlin 1990; L'Imaginaire du sabbat. Edition critique des textes les plus anciens (1430 c. - 1440 c.), éd. M. Ostorero, A. Paravicini Bagliani, K. Utz Tremp, Lausanne 1999.

10 M. Ostling, Babyfat and Belladonna. Witches' Ointment and the Contestation of Reality, „Magic, Ritual, and Witchcraft" 2016, vol. XI, No. 1, s. 34. 
Noc Walpurgii (30 kwietnia $)^{11}$. Sabaty powszednie odbywały się średnio raz-trzy razy $\mathrm{w}$ tygodniu ${ }^{12}$. Wśród demonologów nie ma zgody co do dni tygodnia. Zgodnie z zeznaniami czarownic najczęściej były to poniedziałki, środy i piątki, chociaż równie często pojawia się w zeznaniach czwartek ${ }^{13}$. Spotkania odbywały się w nocy, a kończył je krzyk koguta i nadchodzący świt ${ }^{14}$. Sabat dzielił się na konkretne etapy. Pierwszym z nich było przybycie czarownic. Istniało wiele jego możliwości, najpopularniejszą był lot na miotle lub widłach ${ }^{15}$. Czarownica mogła też dotrzeć na spotkanie, dosiadając zwierzęcia, np. kozła lub maciorę, lub dojechać płonącym wozem, zaprzęgniętym w czarne konie ${ }^{16}$. Aby dostać się na sabat za pomocą lotu, niezbędne było posmarowanie się specjalną maścią, w której skład wchodziły rośliny mające działanie narkotyczne, halucynogenne i trujące, takie jak np. blekot, cykuta, psianka ${ }^{17}$. Innym sposobem dotarcia na sabat było wysłanie nań duszy a zostawienie ciała $\mathrm{w}$ łóżku ${ }^{18}$. Spotkanie zaczynało się od oddania hołdu szatanowi ${ }^{19}$, następnie dochodziło do dzikich tańców oraz uczty ${ }^{20}$. Jeśli chodzi o dania, którymi raczyły się czarownice podczas sabatu, znów nie ma zgody wśród demonologów. Jedni uważali, że jedzono prawdziwe jedzenie, to, które zostało przyniesione przez czarownice ${ }^{21}$, drudzy byli zdania, że dania, które znajdowały się na stołach podczas sabatów były pozbawionym smaku złudzeniem, w rzeczywistości będąc fekaliami ${ }^{22}$. Nieodłącznym elementem sabatu była orgia, podczas której czarownice współżyły nie tylko z samym diabłem, lecz także dochodziło do seksu homoseksualnego i kazirodczego 23 .

Jeden z pierwszych opisów sabatu znany jest dzięki zeznaniom w trakcie procesu, jaki odbył się w Tuluzie w 1335 r. Podczas tortur dwie kobiety oświadczyły, że od 20 lat

11 A. Szczepaniak-Knoll, Sabat w kulturze ludowej Pomorza, „Nasze Pomorze. Rocznik Muzeum Zachodnio-Kaszubskiego w Bytowie” 2001, nr 3, s. 10. Wśród dat wielkich sabatów można dodać: 2 II, 23 VI, 1 VIII i 21 XII. Vide: R.H. Robbins, Encyklopedia czarów i demonologii, przekł. M. Urbański, Warszawa 1998, s. 264. Więcej na ten temat: J. Adamowski, Czas i częstotliwość tysogórskich sabatów czarownic, „Annales Universitatis Mariae Curie-Skłodowska, sectio FF - Philologiae” 1996/1997, vol. XIV/XV, s. 399-409.

12 A. Szczepaniak-Knoll, op. cit., s. 9.

13 R.H. Robbins, op. cit., s. 265.

14 Hexe, [w:] Handwörterbuch des deutschen Aberglaubens, Bd. III, hrsg. H. Bächtold-Stäubli, BerlinNew York 1987, szp. 1890.

15 Ibidem, szp. 1883.

16 Ibidem, szp. 1884. Dokładniej na temat „przykładowej” drogi na sabat pisał: J. Adamowski, Droga na tysogórski sabat czarownic, „Kultura Ludowa” 2000, nr 3(44), s. 23-35.

17 K. Baschwitz, Czarownice. Dzieje procesów o czary, przekł. T. Zabłudowski, Warszawa 1999, s. 100.

18 Hexe..., szp. 1885.

19 Bardzo często dochodziło również do odbycia parodii mszy świętej. Należy jednak pamiętać, że nie używano wtedy terminu „czarnej mszy”. Vide: B.P. Levack, Polowanie na czarownice w Europie wczesnonowożytnej, Wrocław 2009, s. 60.

20 R.H. Robbins, op. cit., s. 267-269.

21 Ibidem, s. 268.

$22 \quad$ Hexe..., szp. 1887.

23 B.P. Levack, op. cit., s. 60. 
służą szatanowi i raz w tygodniu zapadają w sen, podczas którego udają się na sabat, gdzie diabeł raczy ich ucztą oraz uczy magicznych sztuczek ${ }^{24}$. Wraz z nasileniem procesów o czary przygotowywano odpowiednio dobrane zestawy pytań, które miały być pomocne w przesłuchiwaniu osób oskarżonych o praktyki czarostwa. Jednymi z bardziej znanych przykładów takich zestawów są te znajdujące się w aktach miasta Kelheim, zwane Kelheimer Hexenhammer ${ }^{25}$. Rękopis zatytułowany Absoluta generalia circa Confessionem veneficarum. Fragstuckh auf alle Articul, in welchen die Hexen vnd vnholden auf das allerbequemist möge Examinirt werden zawiera 12 rozdziałów, w tym 97 pytań, które miały pomóc w odkryciu crimen magiae oskarżonych o uprawianie magii. Wśród pytań znalazły się też te związane z podróżą na sabat, dość szczegółowe. Dotyczą one nie tylko częstotliwości, lecz także tego, jakie słowa były wypowiadane przed udaniem się na zlot, czym latano, co w czasie spotkania pito, co jedzono. Nie zabrakło również pytania o destynację: An welche örther sie khommen, wie sie haissen?26.

Miejscem, które bezsprzecznie kojarzy się z sabatem czarownic, jest góra. Wybór wzniesienia jako miejsca takich spotkań nie było dziełem przypadku. Ma ono szerokie znaczenie $\mathrm{w}$ wierzeniach $\mathrm{i}$ jest związane $\mathrm{z}$ wieloma mitami. Jako miejsce wyróżniające się, wypiętrzone i wręcz dysfunkcyjne mogło być postrzegane jako stworzone przez siły demoniczne ${ }^{27}$. Również droga w zaświaty często związana była z drogą „,ku górze” i dlatego w świadomości społecznej góry często łączyły się z zaświatami ${ }^{28}$. Nacechowane szczególnie negatywnie, były postrzegane jako obszar zamieszkany przez demony, dlatego też stawały się idealnym miejscem spotkań czarownic ${ }^{29}$. Rzecz jasna, należy też wziąć pod uwagę to, że szczyt góry był oddalony od siedzib ludzkich, co sprawiało, że nikt nie miał możliwości zobaczenia czarownic ${ }^{30}$.

W masowej wyobraźni dominują szczególnie dwa wzniesienia, które według wierzeń i podań związane były z sabatami czarownic. Są to Łysa Góra oraz Blocksberg (Góra Brocken - il. 1) $)^{31}$. Szczyt w Górach Świętokrzyskich jest owiany nimbem tajemnicy. Przyczyną tego są nie tylko legendy dotyczące odbywających się tam rzekomo sabatów,

$24 \quad$ Hexe..., szp. 1846.

25 C. Daxelmüller, Aberglaube, Hexenzauber, Höllenängste. Eine Geschichte der Magie, München 1996, s. 162.

26 Ibidem, s. 163.

27 P. Kowalski, Leksykon znaki świata. Omen, przesąd, znaczenie, Warszawa-Wrocław 1998, s. 142.

28 Ibidem, s. 147.

29 Ibidem, s. 147-148.

30 Taką argumentację podał niejaki Mathäus Perger, który został oskarżony o czary w 1645 r. Proces toczył się na terenie południowego Tyrolu. Vide: H. Rabanser, Hexenwahn. Schicksale und Hintergründe. Die Tiroler Hexenprozesse, Innsbruck-Wien 2006, s. 170

31 Ciekawym przypadkiem góry, na której spotykały się czarownice, jest szwedzka Blåkulla, która w rzeczywistości nie istnieje; początkowo identyfikowano ją z Blå Jungfrun. Źródłowe opisy tego miejsca bardzo się różnią: raz jest to miejsce piękne, innym razem straszne niczym piekło. Opisy Blåkulli w dużym stopniu pochodzą z zeznań dzieci (w Szwecji popularny był motyw porywania dzieci przez trolle). Vide: R.M. Golden, Encyclopedia of Witchcraft. The Western Tradition, Greenwood 2006, s. $126-127$. 


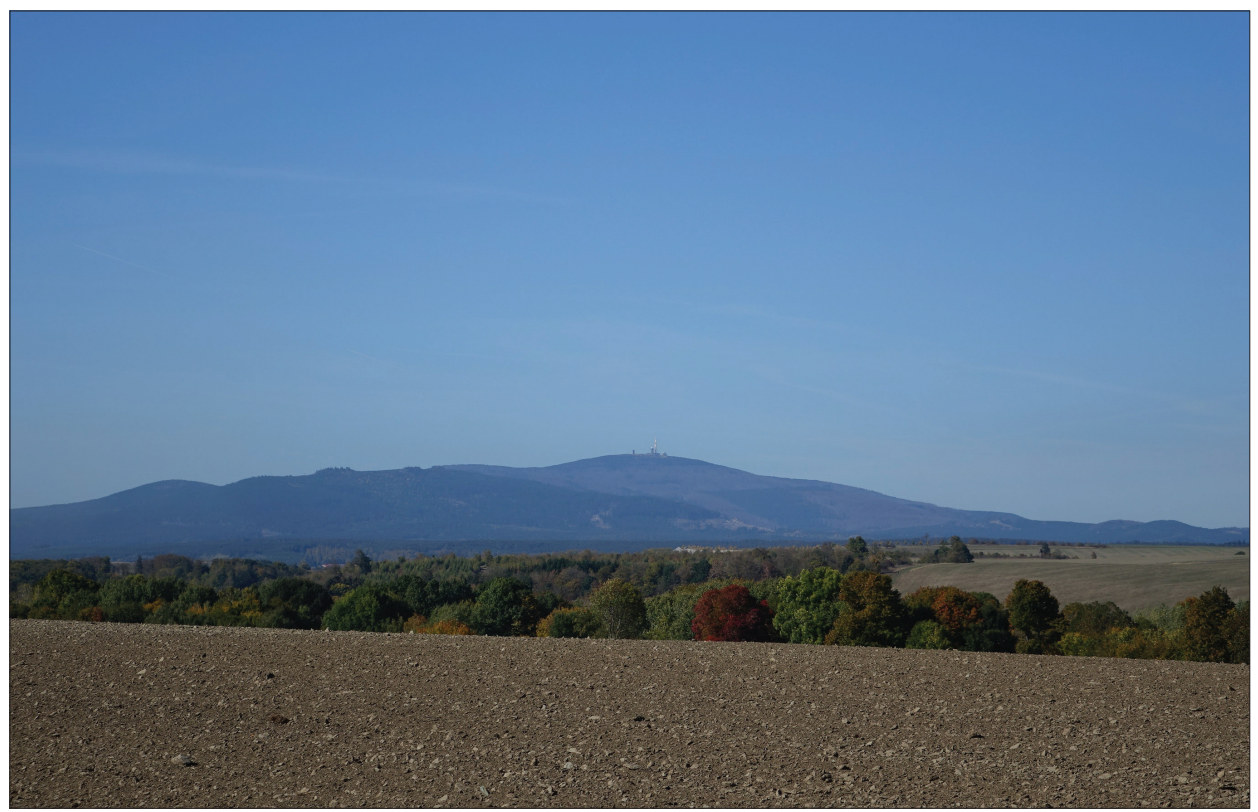

1. Widok na Górę Brocken - miejsce sabatów czarownic w Górach Harzu (Niemcy). Fot. D. Wojtucki

lecz także pogańska przeszłość wzniesienia ${ }^{32}$. Według legend jeszcze w 1686 r. znaleziono tam „bożyszcze dawne węglem osypane”, a na początku XIX w. odnajdywano urny z prochami zmarłych ${ }^{33}$. Z badań Małgorzaty Pilaszek wynika, że idea sabatu na ziemiach Rzeczypospolitej pochodziła z zagranicy i wśród społeczeństwa Korony zyskała większą popularność dopiero w XVII i XVIII w. ${ }^{34}$ W przypadku tego obszaru koncept sabatu $\mathrm{z}$ reguły nie odgrywał głównej roli w oskarżeniach stawianych czarownicom. Częściej występuje on w dokumentach procesów, które dotyczą terenów, na których możliwy był kontakt z ludnością niemieckojęzyczną ${ }^{35}$. Warte zaznaczenia jest również to, że samo słowo „sabat” nigdy nie pojawia się w protokołach zeznań czarownic. Zamiast tego występują takie określenia, jak: „biesiada”, „sejm”, „schadzka”, „czartowski bankiet”36. Czarownice z terenów Korony zeznawały o swojej obecności na Łysej Górze np. w latach $1660^{37}$ i $1685^{38}$.

J. Stankiewicz, Legendy świętokrzyskie, Kielce 2002, s. 3.

Ibidem.

M. Pilaszek, Procesy o czary w Polsce w wiekach XV-XVIII, Kraków 2008, s. 441.

Ibidem, s. 443. Jako przykład mogą posłużyć procesy z miejscowości Nowe nad Wisłą oraz Fordon.

Ibidem, s. 439.

Ibidem, s. 445.

Ibidem, s. 440. Niezwykle interesującym zagadnieniem wydaje się prześledzenie historii występowania Łysej Góry w kontekście miejsca sabatu np. w aktach procesowych. 
Drugie wspomniane wzniesienie, Brocken (Blocksberg), mierzący 1142 m n.p.m., najwyższy w środkowej części Niemiec ${ }^{39}$, położony jest w Górach Harzu. Jest to góra o bardzo długiej tradycji odbywania na niej sabatów. Już około 1700 r. wiadomo było, że w Noc Walpurgii spotykają się tam czarownice. Jak napisał Georg Henning Behrens, autor dzieła Hercynia Curiosa oder Curiöser Hartz-Wald:

Dieser Berg ist weit und breit, so wohl durch gantz Teutsch - Land, als auch auswertig in fremden Landen, sehr berühmt [...], Weil auch die Kinder davon zu sagen wissen: wie nemlich alle Jahr darauff die Hexen aus Teutsch - Land in der Wapurgis Nacht [...] sich versammleten, und daselbst mit denen bösen Geistern durch einen Schmaus und Tanz, lustig machen ${ }^{40}$.

Brocken pojawił się w źródłach w XV w., najprawdopodobniej już wtedy jako Hexenberg, czyli „góra czarownic”⒈ Pewna jest natomiast data 1540 r., gdy guślarka Grete Wroistes z Elbingerode opowiedziała o locie na Górę Brocken w Noc Walpurgii ${ }^{42}$. Popularność tego miejsca wzrosła w drugiej połowie XVII w., kiedy zostało opublikowane dzieło Johannesa Praetoriusa Blockes-Berge Verrichtung, który opisał je nie tylko pod względem geograficznym, lecz także przedstawił kompilację ówczesnej wiedzy na temat czarownic w iście barokowym stylu ${ }^{43}$. Pod koniec XVIII w. topografia, wskutek mody związanej z romantyzmem, uległa magii, tzn. wiele obszarów zyskało przydomek „magiczny” lub „zaczarowany”, a na początku XIX stulecia uległa z kolei urokowi czarownic. Na mapach zaczęły pojawiać się nowe nazwy, również okoliczni mieszkańcy zaczynali nazywać pewne obszary na nowo. Dobrym przykładem jest jedno z miejsc w Górach Harzu, które nosiło nazwę Zauberbrunnen (pol. czarodziejska studnia), po czym zmieniono ją na Hexenbrunnen (pol. studnia czarownic) ${ }^{44}$. Większe grono ludzi poznało bliżej Brocken dzięki Johannowi Wolfgangowi Goethemu, który umieścił ją w tragedii Faust.

39 I. Köhler-Zülch, Die Hexenkarriere eines Berges: Brocken alias Blocksberg. Ein Beitrag zur Sagen-, Hexen- und Reiseliteratur, „Narodna umjetnost: hrvatski časopis zu etnologiju i folkloristiku” 1993, vol. XXX, No. 1, s. 47.

40 G.H. Behrens, Hercynia Curiosa oder Curiöser Hartz-Wald, Nordhausen 1703, s. 136: „Góra ta znana jest wzdłuż i wszerz w całych Niemczech, jak i zagranicą [...], bo i dzieci wiedzą i opowiadają, że co roku w noc Walpurgii zbierały się tu czarownice z całych Niemiec, i ze złymi duchami bawiły się wesoło, ucztując i tańcząc" - wolny przekł. K.W.

41 I. Köhler-Zülch, op. cit., s. 54. Należy rozwiać przypuszczenia, jakoby do traktowania Brockenu jako góry czarownic przyczyniło się zjawisko „widma Brockenu”. Zostało ono zaobserwowane dopiero w XIX w.

42 Ibidem, s. 54, przyp. 32. Z licznych opracowań dotyczących Góry Brocken warto polecić: E. Jacobs, Der Brocken und sein Gebiet, Wernigerode 1871.

43 J. Praetorius, Blockes-Berge Verrichtung, Leipizg 1668-1669. Dzieło to zawiera również jedno z najpopularniejszych przedstawień sabatu czarownic na Górze Brocken.

44 I. Köhler-Zülch, op. cit., s. 57. 


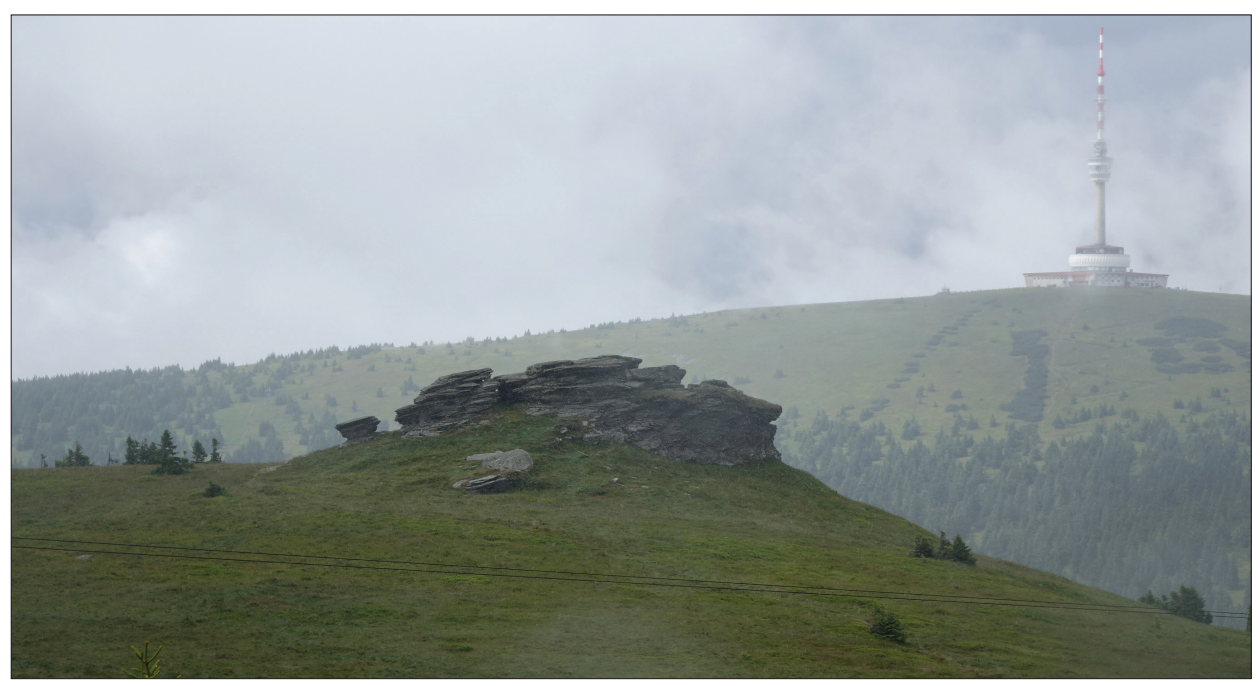

2. Grupa skałek Petrovy Kameny pod Pradziadem (Czechy) - miejsce sabatów śląskich i morawskich czarownic. Fot. D. Wojtucki

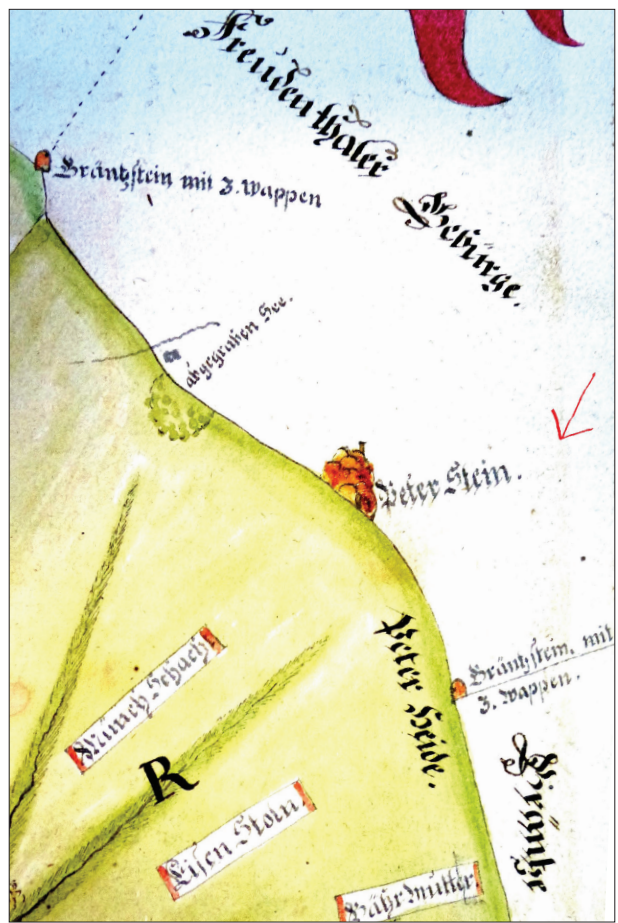

3. Petrovy Kameny zaznaczone na osiemnastowiecznej mapie rękopiśmiennej.

Widoczny dokładny przebieg pasa granicznego. Fot. D. Wojtucki

(Źródło: Zemský archiv v Opavě, pobočka Olomouc) 
Obie wspomniane góry: Łysa Góra oraz Blocksberg pełniły dwojaką funkcję. Po pierwsze, uznawane były za wzniesienia, na których spotykały się czarownice. Po drugie, stały się symbolem miejsca sabatów. Od ich nazw zaczęto więc tak określać inne miejsca schadzek czarownic z czartami. Protokoły sądowe z terenów Korony z XVII i XVIII w. zawierają ciekawe informacje na temat różnych „łysych gór”. Znajdowały się one m.in. na dębie, na wierzbie, pod bożą męką, w lesie świerkowym, nad sadzawką, „za łąką Maćkową”, w młynie koło lasu itp..$^{45}$ Różnego rodzaju „blocksbergi” zaczęły się z kolei pojawiać w innych regionach Europy. Na terenie Rzeszy nazwa ta stała się symbolem miejsca spotkań czarownic ${ }^{46}$. Oswald Kurtz wyczerpująco wyjaśnit, że identyfikowanie każdego blocksbergu jako wzniesienia w Górach Harzu jest błędne, gdyż każdy większy obszar miał swój „blocksberg” ${ }^{47}$. Nie jest więc prawdą, że nazwa ta oznaczała zawsze tylko i wyłącznie właściwy Blocksberg, czyli Górę Brocken ${ }^{48}$.

Na pograniczu śląsko-morawskim także istnieje miejsce, w którym z reguły miały odbywać się spotkania czarownic. Jest to grupa skalna nazywana Petrovy Kameny (niem. Peterstein, pol. Skały Piotrowe), powszechnie znana turystom, leżąca na ramieniu Vysokie Hole, w głównym grzbiecie Wysokiego Jesionika na wysokości 1438 m n.p.m. (il. 2 i 3$)^{49}$. Nazwa tej formacji skalnej nawiązuje do postaci św. Piotra. Według legendy w okolicach tych zagubił się jeden z okolicznych grafów. W akcie rozpaczy pomodlił się do św. Piotra, który mu się ukazał i wskazał drogę powrotną. Od tego czasu góra i leżące na niej kamienie są nazwane od imienia tego świętego ${ }^{50}$. Drugie podanie związane jest z parą zakochanych, która uciekła z rodzinnej miejscowości, ponieważ rodzice dziewczyny nie wyrazili zgody na ich związek. Gdy wyczerpani i bliscy śmierci znaleźli się w pobliżu skał, zaczęli się modlić do św. Piotra, który pojawił się wśród grzmotów i błyskawic. Zabrał nieszczęsną parę w okolice Karlsbrunn ${ }^{51}$, z nadzieją, że zalegalizują swój związek. Tak też się stało. Od tej pory skały te noszą nazwę Peterstein ${ }^{52}$.

45 Vide: K. Koranyi, Eysa Góra. Studium z dziejów wierzeń ludowych w Polsce w XVII i XVIII wieku, „Lud” 1928, seria 2, t. VII(XXVII), s. 60.

46 I. Köhler-Zülch, op. cit., s. 53.

47 O. Kurtz, Beiträge zur Erklärung des volkstümlichen Hexenglaubens in Schlesien, Anklam 1916, s. 33. Zagadnienie to poruszył również J. Wijaczka, Polowanie na czarownice i czarowników w Nowem nad Wista i najblizszej okolicy miasta w XVII i pierwszej potowie XVIII wieku, „Czasy Nowożytne” 2009, t. XXII, s. 119-144. Czarownice z tamtego obszaru spotykały się na sabatach m.in. pod zamkiem nowskim, na górze niedaleko klasztoru pelplińskiego, w miejscu nad Wisłą, gdzie gromadzono drewno do splawu (ibidem, s. 130).

48 Tego zdania jest A. Szczepaniak-Kroll, op. cit., s. 9.

49 P. Mrugalski, Wielkie polowanie. O czarownicach, sabatach i ptonacych stosach, [Pielgrzymy. Informator krajoznawczy poświęcony Sudetom], Wrocław 1998, s. 48.

50 A. Peter, Volksthümliches aus Österreichisch-Schlesien, Bd. II (Sagen und Märchen. Bräuche und Volksaberglauben), Troppau 1867, s. 125-126.

51 Obecnie miejscowość Karlova Studánka.

52 A. Peter, op. cit., s. 125-126. 
Nazwa Petrovy Kameny jako miejsce sabatu pojawia się w wielu zeznaniach osób oskarżonych o czary ${ }^{53}$. Kaspar Sattler podczas procesu w styczniu 1683 r. opisał dość szczegółowo, jak wyglądało takie spotkanie na „Petri Steinen”, wymieniając z imienia i nazwiska osoby, które tam spotkał, m.in. proboszcza z Rýmařova i Marię Sattler wraz z Krzysztofem Alojzym Lautnerem, którzy mieli zasiadać tuż obok samego księcia piekieł ${ }^{54}$. Podczas procesów o czary w dobrach Žerotinóv zadawano wprost pytanie o to, czy oskarżona bywała na Petrovych Kamenach: „Bist Du nach diesel ufam Peterstein zu der allgemeine Hexenzusammenkunft und auf was Weise gefahren?” (Czy bywałaś na Peterstein na spotkaniu czarownic i w jaki sposób tam przybywałaś? - przekł. K.W.). Zeznająca w 1684 r. Katharina Winter odpowiedziała: ,ja, ich bin nach dem ich mich ergeben auf den Peterstein zu der allgemeinen Hexenzusammenkunst kommen" (tak, po poddaniu się [diabłu], przybywałam na spotkanie czarownic na Peterstein przekł. K.W. $)^{55}$.

Obszar ten, mimo że nazwano go ku czci świętego i związany jest legendarnie z jego obecnością, uważany był za miejsce kumulacji złych mocy. Dlaczego właśnie te skały stały się miejscem sabatów? Na pewno wiąże się to z tym, że jest wzniesieniem, które jak wyjaśniłam - „z natury” odbierane było jako miejsce magiczne. Być może nietypowa formacja skalna na tej górze również odegrała pewną rolę. Ponadto należy pamiętać, że miejsce to leżało na granicy morawsko-czeskiej. W wierzeniach ludowych granica była miejscem niezwykłym. Przejście przez granicę, czy to pomiędzy państwami, czy w obrębie kraju, z jednej prowincji do drugiej, miało charakter nie tylko polityczny czy ekonomiczny, lecz także magiczno-religijny. Osoba, która dokonywała takiego przejścia, znajdowała się przez krótką chwilę w sytuacji zawieszenia między dwoma światami ${ }^{56}$. Oprócz tego granica, z racji tego, że nie przynależała do żadnego ze światów, była doskonałym miejscem ukrycia się wszelkich duchów, demonów i złych mocy ${ }^{57}$. Miejsce to wzbudzało lęk do tego stopnia, że cesarz Leopold Habsburg za zgodą ołomunieckiego konsystorza zarządzil, aby skały skropić wodą święconą,

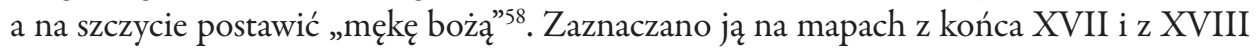

53 P. Mrugalski, op. cit., s. 49; M. Neubauerová, D. Polách, Zpráva o neviŕre / Raport o niewierze / Die Nachricht vom Unglaube, [b.m.w.] 2010, s. 70-71. Miejsce to było również związane z wierzeniami, w myśl których znajdują się tam ukryte skarby. Więcej na ten temat: K. Wojtucka, Poszukiwanie skarbów za pomoca magii na nowożytnym Ślasku i Morawach. Przyczynek do badań, „Klio” 2020, t. LIII, z. 2, s. 163-181.

54 P. Kreuz, Die späten Hexenprozesse in den böhmischen Ländern und auf dem Gebiet der heutigen Slowakei, [w:] „Hexenforschung”, Bd. XIV (Späte Hexenprozesse. Der Umgang der Aufklärung mit dem Irrationalen), hrsg. W. Behringer, S. Lorenz, D.R. Bauer, Bielefeld 2016, s. 177.

55 Soudní protokoly inkviziční komise, relace Sybile z Galle, Zemský archiv v Opavě, pobočka Olomouc, Rodinný archiv Žerotínů-Bludov 1427-1947, karton 56, sygn. 578, k. 6080.

56 A. van Gennep, Obrzędy przejścia, przekł. B. Biały, Warszawa 2006, s. 43.

57 Na temat magicznego znaczenia granic vide: S. Bylina, Drogi - granice - most. Studia o przestrzeni publicznej i sakralnej w średniowieczu, Warszawa 2012, zwłaszcza s. 43-88.

58 P. Mrugalski, op. cit., s. 49. „Boża męka” w języku potocznym była określeniem dla figury lub krzyża z wyobrażeniem ukrzyżowanego Jezusa Chrystusa. 
stulecia. Dnia 20 czerwca 1682 r., w momencie, kiedy w okolicznych miejscowościach odbywały się krwawe procesy o czary, dokonano poświęcenia tego miejsca ${ }^{59}$. Na szczycie ustawiono kamienny słup z reliefem lub obrazem o przedstawieniu maryjnym, którego pozostałości można było oglądać jeszcze w XIX w. ${ }^{60}$ Według Richarda Kühnaua, autora zebranych Schlesischen Sagen, działania takie miały sprawić, że miejsce to już nie będzie mogło być używane przez czarownice jako miejsce spotkań ${ }^{61}$.

Autor dzieła Beiträge zur Erklärung des volkstümlichen Hexenglaubens in Schlesien, Oswald Kurtz, wymienił jeszcze inne wzgórza, na których miały się odbywać sabaty: Gückelsberge na Łużycach, Pangelberg przy Niemczy, Hexenberg w pobliżu Bierutowa, a nawet same Karkonosze (niem. Riesengebirge) ${ }^{62}$. Jak z tego wynika, miejsc, w których spotykały się czarownice, było dużo więcej i nie musiały to być jedynie góry albo wzniesienia. Czy miało to coś wspólnego z rangą spotkania (sabat w ciągu tygodnia czy w Noc Walpurgii) i dniem tygodnia - trudno powiedzieć. Takie ujęcie tematu wymaga precyzyjnej kwerendy i badań źródłowych. Trudno jest także przewidzieć, czy uda się znaleźć odpowiedź na tak postawione pytanie.

Wśród miejsc, w których można było spotkać czarownice, można również wymienić skrzyżowania dróg, miejsca, gdzie krzyżują się kondukty żałobne, rozgałęzienia dróg, małe laski, łąki, zwłaszcza tam, gdzie nie rośnie trawa lub widać „trującą pleśń”, a ponadto obszary, gdzie grzyby rosną w tzw. czarcim kręgu, okręgi, w których nie rośnie trawa lub nic nie chce rosnać. Miejscem schadzek mogły też być tereny, na których trawa była ciemniejsza, wyższa, bujniejsza. Dlatego właśnie występują liczne obszary, których nazwy zawierają człon Hexe, np. Hexentanzplatz, Hexenringe, Hexenwiese ${ }^{63}$. Wspomniany Kurtz wymienił też Hexenplan (il. 4 i 5), zielone łąki, czarny zamek na wysokiej górze. Pojawiło się również wyjątkowo ciekawe stwierdzenie, że jest to miejsce „sto mil oddalone od domu" ${ }^{64}$. Podsumowując, były to miejsca wyróżniające się w jakiś szczególny sposób, czego nie potrafiono wytłumaczyć. Dziś już zrozumiały jest mechanizm powstawania np. tzw. czarcich kręgów, które związane są z toksycznymi związkami zawartymi w niektórych grzybach. Sam okrąg również łączył się z konkretnymi folklorystycznymi wierzeniami ${ }^{65}$. Rozdroże było miejscem epifanicznym i demonicznym. Przeświadczenie o jego niezwykłości można spotkać u Greków, Germanów i Słowian. Oprócz

59 K. Wojtucka, Petrovy Kameny pod Pradziadem - morawski Brocken. Miejsce sabatów czarownic w XVII wieku, „Pomniki Dawnego Prawa” 2018, z. 42, s. 42 oraz il. 7.

60 P. Mrugalski, op. cit., s. 50. Niektórzy dopatrywali się w postawionej „bożej męce” kolumny piotrowej. Vide: E. Schwarz, Sudetendeutsches Flurnamen-Buch, Reichenberg 1937, s. 64.

61 R. Kühnau, Schlesische Sagen III. Zauber-, Wunder-und Schatzsagen, Leipzig 1913, s. 10.

62 O. Kurtz, op. cit., s. 33-34.

$63 \quad$ Hexe..., szp. 1881.

64 O. Kurtz, op. cit., s. 34.

65 Koło z reguły miało walory protekcyjne i służyło ochronie tego, co w kręgu było umieszczone. Czynność zakreślania okręgu miała również wartość apotropeiczną, jednak w przypadku wierzeń w czary koło lub okrąg pojawia się w połączeniu z czarownicą, np. według wierzeń czarownice podczas sabatu tańczyły w okręgu. W takim przypadku okrąg pełnił funkcję magiczną, ale nie ochronną; chyba że 
kwestii czysto moralnej: na rozdrożu należało podjąć decyzję, związane ono było także z miejscem szczególnie upodobanym przez demony i złe siły. Dlatego też rozstaje dróg idealnie nadawały się do spotkań czarownic ${ }^{66}$. Mogły to być również drzewa, takie jak lipa i dąb, oraz kamienie ${ }^{67}$. Wśród drzew zwłaszcza dwa gatunki zyskały sławę miejsc sabatów: dąb i wierzba. Dąb, często kojarzony z bogami i różnymi mocami poprzez to, że przyciągał pioruny, związany był też z właściwościami mediacyjnymi ${ }^{68}$. Pojawiający się w wielu wierzeniach wątek dębu jako środka świata lub osady sprawiał, że było to miejsce, gdzie otwierają się drogi nie tylko do niebios, lecz także ku mrocznym zaświatom $^{69}$. Z kolei wierzba zajmowała niezwykłe miejsce w wierzeniach Słowian. Uważana była za siedlisko demonów oraz dusz nieczystych osób zmarłych. Stare polskie przysłowie mówi: „W starej wierzbie diabeł mieszka”. Stare i samotne wierzby były wręcz idealnym miejscem na sabat ${ }^{70}$. Szczególnym terenem było też miejsce straceń z szubienicą. Ponieważ był to plac, na którym przelewano krew oraz znajdowały się tam pochówki ludzi niegodnych i samobójców, uważano, że jest to miejsce magiczne. Dostarczało ono artefaktów potrzebnych zarówno do uprawiania magii, jak i do leczenia. Mogły to być części ciała skazańców, sznury wisielców oraz zioła rosnące na Górze Szubienicznej ${ }^{71}$. Wśród miejsc wymienionych przez Oswalda Kurtza znajdziemy również takie - jest to Góra Szubieniczna przy miejscowości Mladkov (niem. Galgenberg bei Wichstadel) ${ }^{72}$.

Nie zawsze jednak było tak, że miejsce spotkań czarownic otrzymywało jakąś szczególną nazwę. Dobrym przykładem są tu zeznania oskarżonych o czary nastolatków, którzy byli przesłuchiwani przez sąd ząbkowicki. Hans Krause poświadczył, że niejaka Susanne Hellerin uczyła go czarów. Postawiona przed wymiarem sprawiedliwości dziewczyna zeznała, że magii uczyła się od matki oraz że bywała na spotkaniach, podczas których tańczono „auf ein Wiesen bei Puschwalde” (na łące przy Puschwalde przekł. K.W. ${ }^{73}$. Hans Kärtner z kolei bywał na spotkaniach czarownic, jednak nie odbywały się one na żadnych górach ani na metaforycznych blocksbergach, tylko w okolicznym zagajniku o nazwie „Frenzel Büsche”74.

krąg ten miałby chronić czarownice. Temat ten jednak wymaga analizy i opracowania. Vide: P. Kowalski, op. cit., s. 233.

66 Ibidem, s. 91-92.

${ }^{67}$ Hexe..., szp. 1881.

68 P. Kowalski, op.cit., s. 78.

69 Ibidem.

70 Ibidem, s. 595.

71 P.A. Jeziorski, Margines spoteczny w dużch miastach Prus i Inflant w późnym średniowieczu i wczesnych czasach nowożytnych, Toruń 2009, s. 481.

72 O. Kurtz, op. cit., s. 35.

73 Acta über einen der Hexerei Beschuldigten vierzehnjährigen Bauerknaben, Archiwum Państwowe we Wrocławiu [dalej: APWr], Akta księstwa ziębickiego, sygn. 231, s. 4.

74 E. Wieczorek, Bericht über zwei in den Jahren 1653/1654 gegen Kinder geführte Hexenprozesse, „Unsere Heimat. Monatsblätter für Heimatkunde und Heimatkultur. Beilage zur Frankenstein-Münsterberger Zeitung" 1929/1930, Jg. VI, s. 15. Więcej na temat tego procesu: K. Wojtucka, Procesy o czary 


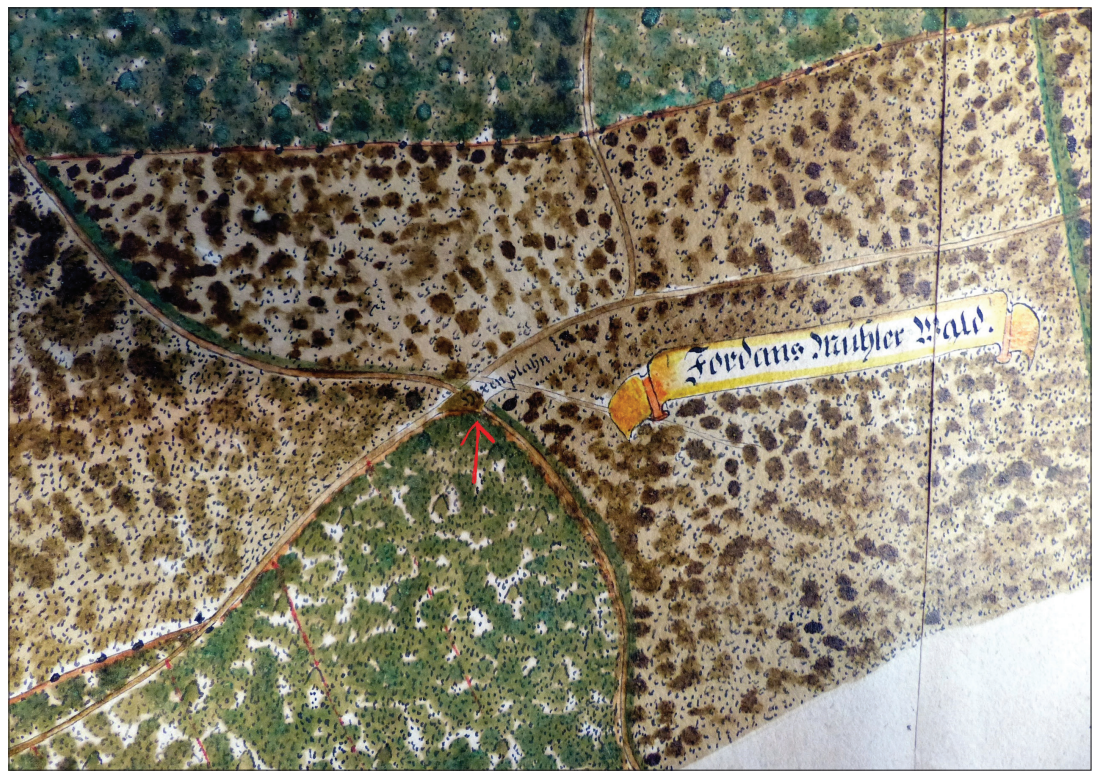

4. Hexenplan na rozdrożu w pobliżu miejscowości Jordanów Śląski. Fot. D. Wojtucki (Źródło: Zemský archiv v Opavě, pobočka Olomouc)

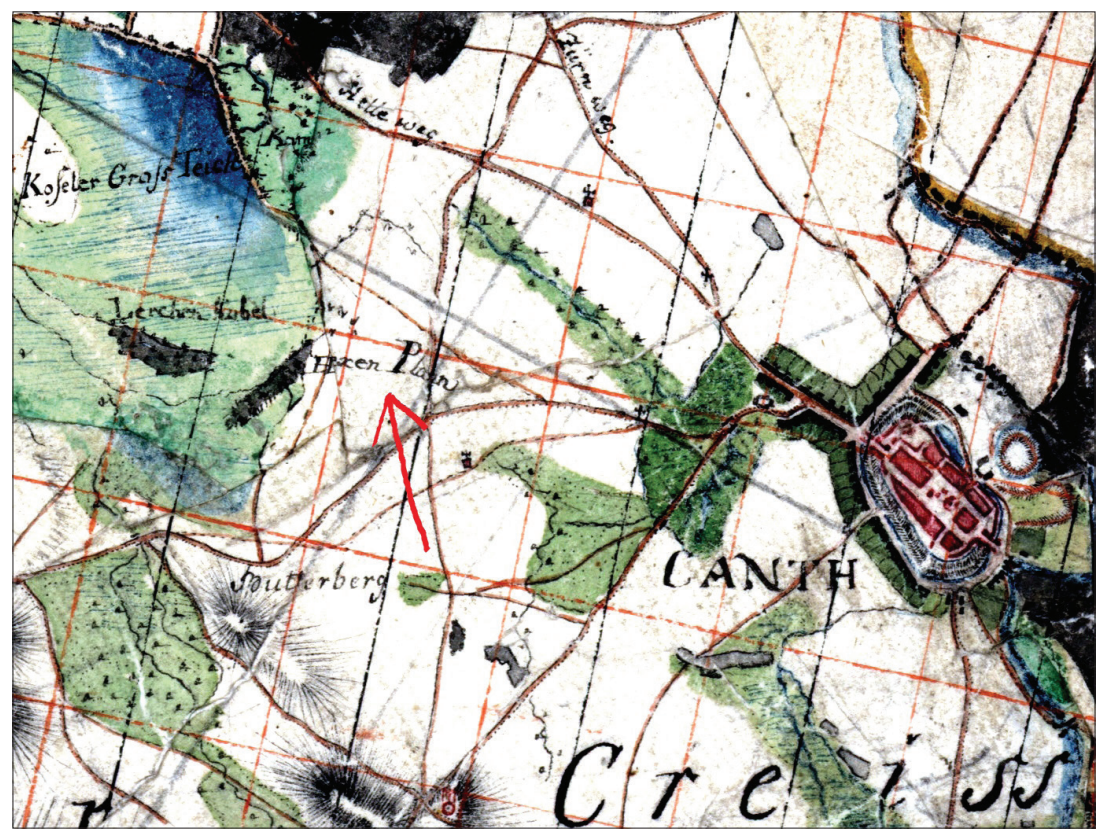

5. Hexenplan na zachód od miasta Kąty Wrocławskie zaznaczony na osiemnastowiecznej mapie rękopiśmiennej (Źródło: Staatsbibliothek zu Berlin, Preußischer Kulturbesitz, sygn. IIIC, Kart N 15140, arkusz nr 52) 
Należy pamiętać, że człon Hexe występujący w danej nazwie topograficznej nie zawsze wiązał się z miejscem spotkań czarownic. Wcześniej nadmieniłam, że taka nazwa może być stosunkowo „młoda” i pochodzić z końca XIX w., kiedy to wszystko, co wiązało się z czarownicą, było niezwykle popularne. Druga opcja jest taka, że miejsce tak nazwane mogło być związane z czarownicami, ale poprzez inne wydarzenia, jak np. jej egzekucja. Przykładem takiego pochodzenia nazwy jest Hexenstein w miejscowości Jawornik. Według legendy niedaleko tego miejsca została spalona na stosie czarownica. W rzeczywistości jest to typowy kamień graniczny, który oddzielał teren miejski od księstwa biskupiego ${ }^{75}$. Taką samą nazwę w tym miasteczku nosiły cztery inne kamienie, które były wmontowane w bruk na rynku w pobliżu ratusza. Według innych przekazów było to prawdziwe miejsce spalenia czarownic ${ }^{76}$.

Interesującym przypadkiem jest Hexenplan przy dzisiejszej miejscowości Svobodné Heřmanice (niem. Freihermersdorf). W 1755 r. w tym miejscu spalono nie tylko zwłoki podejrzanej o czary, ekshumowanej w 1753 r. żony żołnierza Wenzela Sellingera, lecz także 19 innych ciał, na których znaleziono podejrzane znaki czarownicy (niem. Hexenmale) ${ }^{77}$. Zagadnienie to związane jest z pojęciem magii pośmiertnej (magia posthuma), która po okresie procesów o czary żywych czarownic wysunęła się na pierwszy plan $^{78}$. Właśnie to wydarzenie sprawiło, że od tego momentu miejsce to zyskało nazwę Hexenplan. Zatem w tym przypadku zdecydowanie nie jest to miejsce sabatów ${ }^{79}$.

Bliżej należy się także przyjrzeć informacji o Hexenbergu i Hexenplanie w Nysie. W pracy regionalnego stowarzyszenia katolickiego (Verein katholischer Lehrer Schlesien) można znaleźć informację, że $2 \mathrm{~km}$ na północ znajduje się Hexenberg, a w miejscu, gdzie dziś jest wieża strażacka, mieści się Hexenplan ${ }^{80}$.

Z kolei w zeznaniach Evy Bäßlerin z Jesenika, która w 1622 r. została oskarżona o czary, można znaleźć informację, że w miejscu o takiej właśnie nazwie (Hexenplan) dochodziło do spotkań czarownic. Kobieta zeznała, że „auf dem Plan Bier getrunken und Fleisch geßen" (na miejscu piła piwo i jadła mięso - przekł. K.W.) ${ }^{81}$. Barbara Schmied również w tym samym roku stwierdziła, że sabaty odbywały się na Hexenplanie $e^{82}$.

w XVII-wiecznych Ząbkowicach Śląskich. Przyczynek do badań, [w:] Wokót dziejów miasta II. 160. rocznica pożaru Ząbkowic Śląskich, Ząbkowice Śląskie 2018, s. 1-9.

75 A. Peter, op. cit., s. 126.

76 Idem, Burgen und Schlösser im Herzogtum Schlesien, Bd. I, Teschen 1879, s. 193.

77 [b.a.], Der „Hexenplan” bei Freihermersdorf, „Freudenthaler Ländchen” 1922, Jg. II, Bd. 2, s. 15.

78 Na temat wierzeń w magię pośmiertną (magia posthuma) vide: D. Wojtucki, Procesy i egzekucje „żywych trupów" przed sądami miejskimi i wiejskimi w XVI-XVIII wieku - przyczynek do wierzeń w magia postbuma na Śląsku, „Opolskie Studia Administracyjno-Prawne” 2018, t. XVI, nr 1, s. 77-92.

79 E. Königer, Der Hexenplan von Freihermersdorf, ,Jägerndorfer Ländchen” 1928, Jg. III, s. 21.

80 [b.a.], Festschrift zur XIII. General-Versammlung des Vereins katholischer Lehrer Schlesiens, Neisse-Pfingsten 1909, s. 8.

81 Peinliche Untersuchung gegen die Barbara Schmidt von Freiwaldau wegen angeschuldigter Zauberei, APWr, Akta księstwa nyskiego, sygn. 381, k. 64.

82 K. Lambrecht, Hexenverfolgung und Zaubereiprozesse in den schlesischen Territorien, Köln 1995, s. 107. 
Niemiecki rzeczownik der Plan ma tu oczywiście inne znaczenie niż to używane dzisiaj. Aby zrozumieć, dlaczego pojawiło się ono w połączeniu z sabatem czarownic, trzeba przyjrzeć się jego etymologii. W dziewiętnastowiecznym słowniku braci Grimm znalazło się kilka znaczeń tego słowa: jest to wolny plac, przeznaczony do różnych celów; może to być publiczne, ważne miejsce w danej miejscowości, np. w pobliżu kościoła lub rynku. Kolejne wytłumaczenie to płaska powierzchnia, szczególnie łąka ${ }^{83}$. Dociekając znaczenia, można jeszcze napotkać informację, że jest to słowiański odpowiednik dla Anger, które oznaczało centralne miejsce w wiosce, używane przez wszystkich mieszkańców w dowolnym celu, np. do organizowania spotkań tanecznych ${ }^{84}$.

Kolejnym miejscem, które być może związane jest z odbywaniem spotkań czarownic, jest dzisiejsza Babia Przełęcz, położona 646 m n.p.m. na Grzbiecie Kamienieckim w Górach Izerskich. Niemiecka nazwa tego miejsca, chętnie używana do dziś przez miejscowych, to właśnie Hexenplatz. Położenie tego obszaru jest szczególne - według podań w pobliżu miała się znajdować pogańska kaplica lub chram, a ponadto krzyżuje się tam aż osiem duktów leśnych ${ }^{85}$. Jasne jest więc, że miejsce to miało wszystkie potrzebne cechy, aby stać się magicznym. Związek tego Hexenplatzu bezpośrednio z czarownicami wymaga dokładniejszych badań regionalnych. Jako obszar spotkań czarownic pojawia się przede wszystkim w śląskich legendach, lecz pamięć o tym miejscu jest wciąż żywa wśród lokalnej ludności, która chętnie odwiedza Plac Czarownic, prawie w ogóle nie używając nowej nazwy nadanej, jaką jest Babia Przełęcz.

Reasumując, zagadnienie związane z miejscami spotkań czarownic jest niezwykle frapujące. Badania nad nim można prowadzić dwojako. Po pierwsze, można przeanalizować jedynie miejsca wymienione w źródłach. Należy jednak pamiętać, że ogrom $\mathrm{z}$ nich nie przetrwał do naszych czasów, zatem dane z akt procesowych będą niepełne. Zatem - po drugie - badania obszarów pojawiających się w miejscowych legendach i tradycjach lokalnych mogą uzupełnić wnioski wynikające z analizy źródeł. Niejednokrotnie bowiem pamięć o pewnych wydarzeniach została na dłużej w danym regionie, wprawdzie nieco przekształconych, lecz zachowujących pewną dozę prawdy. Interesującym zagadnieniem jest również dokładna analiza pojawiających się na mapach miejsc zawierających człon Hexe. Są one doskonałą wskazówką do podjęcia poszukiwań konkretnych informacji w innych źródłach o wskazanym interesującym nas obszarze.

Obraz miejsc sabatów wyłaniający się z przeprowadzonej analizy jest niejednorodny i odstaje od powszechnie przyjętego stereotypu. Okazuje się, że czarownice spotykały się nie tylko na górskich szczytach. Równie często zbierały się w innych miejscach, takich jak łąki, polany, czasami różnego rodzaju ruiny. Wbrew pozorom, nie tylko

83 Plan, [w:] Deutsches Wörterbuch von Jacob Grimm und Wilhelm Grimm, https://woerterbuchnetz. de/ ?sigle=DWB\&lemid=P05213\#0 (dostęp: 19 IX 2020).

84 Informacje na temat Anger: http://dorfanger-blankenburg.de/cms/berlin-blankenburg/dorfanger.

85 L. Różański, Hexenplatz - Babia Przetęcz w Górach Izerskich, „Pomniki Dawnego Prawa” 2018, z. 44, s. 68 . 
wzgórza były dobrym miejscem do uroczystości sabatowych. Wśród miejsc sabatu sporadycznie pojawiają się budynki (najczęściej i tak w postaci ruin), przeważają jednak miejsca typowo przyrodnicze, związane z niczym nieskrępowaną naturą. Być może miejsca te jeszcze bardziej podkreślają więź, jaka łączyła domniemane czarownice z naturą. Zarówno ich umiejętności (znajomość ziół, robienie maści), jak i szkody (grad, chorujące bydło) często związane były ściśle ze światem przyrody. Można jednak wysnuć wniosek, że miejsca spotkań musiały być na swój sposób „magiczne”, wyróżniające się w jakiś sposób, często niezrozumiały dla członków danej społeczności. Analiza tekstów współczesnych pokazuje również, że o ile szczyty górskie przetrwały w wyobraźni powszechnej społeczeństwa, o tyle miejsca sabatów ulokowane w lasach czy na polanach pielęgnowane są w pamięci społeczności lokalnej.

\section{Bibliografia (Bibliography)}

\section{Źródła archiwalne}

Zemský Archiv v Opavě, Pobočka Olomouc

Rodinný archiv Žerotínů-Bludov 1427-1947

Soudní protokoly inkviziční komise, relace Sybile z Galle, karton 56, sygn. 578.

Archiwum Państwowe we Wrocławiu [APWr]

Akta księstwa nyskiego

Peinliche Untersuchung gegen die Barbara Schmidt von Freiwaldau wegen angeschuldigter Zauberei, sygn. 381.

Akta księstwa ziębickiego

Acta über einen der Hexerei Beschuldigten vierzehnjährigen Bauerknaben, sygn. 231.

\section{Źródła drukowane}

Behrens G.H., Hercynia Curiosa oder Curiöser Hartz-Wald, Nordhausen 1703.

Jacobs E., Der Brocken und sein Gebiet, Wernigerode 1871.

Peter A., Burgen und Schlösser im Herzogtum Schlesien, Bd. I, Teschen 1879.

Peter A., Volksthümliches aus Österreichisch-Schlesien, Bd. II (Sagen und Märchen. Bräuche und Volksaberglauben), Troppau 1867.

Praetorius J., Blockes-Berge Verrichtung, Leipzig 1668-1669.

\section{Opracowania}

[b.a.], Der „Hexenplan” bei Freihermersdorf, „Freudenthaler Ländchen” 1922, Jg. II, Bd. 2, s. 15. Adamowski J., Czas i częstotliwość tysogórskich sabatów czarownic, „Annales Universitatis Mariae Curie-Skłodowska, sectio FF - Philologiae" 1996/1997, vol. XIV/XV, s. 399-409. 
Adamowski J., Droga na tysogórski sabat czarownic, „Kultura Ludowa” 2000, nr 3(44), s. 23-35.

Bailey M., Battling Demons. Witchcraft, Heresy, and Reform in the Late Middle Ages, University Park 2003.

Baschwitz K., Czarownice. Dzieje procesów o czary, przekł. T. Zabłudowski, Warszawa 1999.

Bylina S., Drogi - granice - most. Studia o przestrzeni publicznej i sakralnej w średniowieczu, Warszawa 2012.

Daxelmüller C., Aberglaube, Hexenzauber, Höllenängste. Eine Geschichte der Magie, München 1996.

Enzyklopädie der Neuzeit, Bd. V, hrsg. F. Jaeger, Stuttgart 2007.

Festschrift zur XIII. General - Versammlung des Vereins katholischer Lehrer Schlesiens, NeissePfingsten 1909.

Firkowska L., Legendy świętokrzyskie, Kielce 1999.

Frenschkowski M., Die Hexen. Eine kulturgeschichtliche Analyse, Wiesbaden 2016.

Gennep A. van, Obrzędy przejścia, przekł. B. Biały, Warszawa 2006.

Ginzburg C., Hexensabbat. Entzifferung einer nächtlichen Geschichte, Berlin 1990.

Golden R.M., Encyclopedia of Witchcraft. The Western Tradition, Greenwood 2006.

Handwörterbuch des deutschen Aberglaubens, Bd. III, hrsg. H. Bächtold-Stäubli, Berlin-New York 1987.

Jeziorski P.A., Margines spoteczny $w$ dużych miastach Prus i Inflant w późnym średniowieczu i wczesnych czasach nowożytnych, Torun 2009.

Koranyi K., Eysa Góra. Studium z dziejów wierzeń ludowych w Polsce w XVII i XVIII wieku, „Lud” 1928, seria 2, t. VII(XXVII), s. 57-74.

Kowalski P., Leksykon znaki świata. Omen, przesąd, znaczenie, Warszawa-Wrocław 1998.

Köhler-Zülch I., Die Hexenkarriere eines Berges: Brocken alias Blocksberg. Ein Beitrag zur Sagen-, Hexen- und Reiseliteratur, „Narodna umjetnost: hrvatski časopis zu etnologiju i folkloristiku" 1993, vol. XXX, No. 1, s. 47-80.

Königer E., Der Hexenplan von Freihermersdorf, „Jägerndorfer Ländchen” 1928, Jg. III, s. 19-21.

Kramer H. (Institoris), Der Hexenhammer. Malleus Maleficarum, przekł. z łaciny W. Behringer, G. Jerouschek, W. Tschacher, München 2000.

Kreuz P., Die späten Hexenprozesse in den böhmischen Ländern und auf dem Gebiet der heutigen Slowakei, [w:] „Hexenforschung”, Bd. XIV (Späte Hexenprozesse. Der Umgang der Aufklärung mit dem Irrationalen), hrsg. W. Behringer, S. Lorenz, D. R. Bauer, Bielefeld 2016, s. 167-205.

Kurtz O., Beiträge zur Erklärung des volkstümlichen Hexenglaubens in Schlesien, Anklam 1916.

Kühnau R., Schlesische Sagen III. Zauber-, Wunder- und Schatzsagen, Leipzig 1913.

Lambrecht K., Hexenverfolgung und Zaubereiprozesse in den schlesischen Territorien, Köln 1995.

Levack B.P., Polowanie na czarownice w Europie wczesnonowożytnej, Wrocław 2009.

L'Imaginaire du sabbat. Edition critique des textes les plus anciens (1430 c. - 1440 c.), éd. M. Ostorero, A. Paravicini Bagliani, K. Utz Tremp, Lausanne 1999. 
Mrugalski P., Wielkie polowanie. O czarownicach, sabatach i ptonacych, [Pielgrzymy. Informator krajoznawczy poświęcony Sudetom], Wrocław 1998, s. 48-61.

Neubauerová M., Polách D., Zpráva o neviŕre / Raport o niewierze / Die Nachricht vom Unglaube, [b.m.w.] 2010.

Ostling M., Babyfat and Belladonna. Witches' Ointment and the Contestation of Reality, „Magic, Ritual, and Witchcraft" 2016, vol. XI, No. 1, s. 30-72.

Ostling M., Introduction to the Special Issue. How (and Why) Do Witches Fly?, „Magic, Ritual, and Witchcraft" 2016, vol. XI, No. 1, s. 1-5.

Oziębłowski M., Motyw lotu czarownic w tzw. „zbiorczej koncepcji” czarownictwa europejskiego. Świadectwa średniowieczne i wczesnonowożytne, "Almanach Historyczny” 2003, t. V, s. 49-74.

Pilaszek M., Procesy o czary w Polsce w wiekach XV-XVIII, Kraków 2008.

Potkowski E., Czary i czarownice, Warszawa 1970.

Rabanser H., Hexenwahn. Schicksale und Hintergründe. Die Tiroler Hexenprozesse, InnsbruckWien 2006.

Robbins R.H., Encyklopedia czarów i demonologii, przekł. M. Urbański, Warszawa 1998.

Różański L., Hexenplatz - Babia Przetęcz w Górach Izerskich, „Pomniki Dawnego Prawa 2018”, z. 44, s. 68-71.

Schwarz E., Sudetendeutsches Flurnamen - Buch, Reichenberg 1937.

Stankiewicz J., Legendy świętokrzyskie, Kielce 2002.

Szczepaniak-Knoll A., Sabat w kulturze ludowej Pomorza, „Nasze Pomorze. Rocznik Muzeum Zachodnio-Kaszubskiego w Bytowie” 2001, nr 3, s. 7-14.

Wieczorek E., Bericht über zwei in den Jahren 1653/1654 gegen Kinder geführte Hexenprozesse, „Unsere Heimat. Monatsblätter für Heimatkunde und Heimatkultur. Beilage zur Frankenstein-Münsterberger Zeitung” 1929/1930, Jg. VI, s. 12-16.

Wijaczka J., Polowanie na czarownice i czarowników w Nowem nad Wista i najbliższej okolicy miasta w XVII i pierwszej potowie XVIII wieku, „Czary Nowożytne” 2009, t. XXII, s. 119-144.

Wojtucka K., Petrovy Kameny pod Pradziadem - morawski Brocken. Miejsce sabatów czarownic w XVII wieku, „Pomniki Dawnego Prawa” 2018, z. 42, s. 34-46.

Wojtucka K., Poszukiwanie skarbów za pomoca magii na nowożytnym Ślasku i Morawach. Przyczynek do badań, „Klio” 2020, t. LIII, z. 2, s. 163-181.

Wojtucka K., Procesy o czary w XVII-wiecznych Ząbkowicach Śląskich. Przyczynek do badań, [w:] Wokót dziejów miasta II. 160 rocznica pożaru Ząbkowic Śląskich, Ząbkowice Śląskie 2018, s. 1-9.

Wojtucki D., Procesy i egzekucje „żywych trupów” przed sądami miejskimi i wiejskimi w XVI-XVIII wieku - przyczynek do wierzeń w magia posthuma na Śląku, „Opolskie Studia Administracyjno-Prawne” 2018, t. XVI, nr 1, s. 77-92. 


\section{Netografia}

Anger, http://dorfanger-blankenburg.de/cms/berlin-blankenburg/dorfanger (dostęp: 20 IX 2020).

Deutsches Wörterbuch von Jacob Grimm und Wilhelm Grimm, https://woerterbuchnetz.de/ ?sigle=DWB\&lemid=P05213\#0 (dostęp: 19 IX 2020).

Gruber D., Der Hexensabbat. Zeitgenössische Dasrtellungen auf illustrierten Flugblättern, Graz 2013 (maszynopis), https://www.academia.edu/33137136/Master_Thesis_Art_ History_Der_Hexensabbat_Zeitgen\%C3\%B6ssische_Darstellungen_auf_illustrierten_Flugbl\%C3\%A4ttern_Graz_2013_online_unter_http_permalink_obvsg_at AC11065819_(dostęp:1 IX 2020).

Stownik jezyka polskiego, https://sjp.pwn.pl/poradnia/haslo/szabas-szabat-sabat;6819.html (dostęp: 3 IX 2020).

\section{Notka o autorce:}

mgr Karolina Wojtucka - historyk i germanistka, doktorantka w Instytucie Historycznym Uniwersytetu Wrocławskiego. Członek Stowarzyszenia Ochrony i Badań Zabytków Prawa, w ramach którego uczestniczyła w licznych badaniach archeologicznych dawnych miejsc straceń na Śląsku i Górnych Łużycach. Kierownik grantów wewnętrznych, stypendystka w projekcie Sonata Bis finansowanym przez Narodowe Centrum Nauki.

Zainteresowania badawcze: historia nowożytna, procesy o czary, kastelologia, dzieje Śląska, archeologia miejsc straceń, przestępczość kryminalna, wybrane aspekty antropologii i kulturoznawstwa, dydaktyka nauczania historii.

(ㄱarolina.wojtucka@uwr.edu.pl 